\title{
The Cylindrocladium candelabrum species complex includes four distinct mating populations
}

\author{
Conrad L. Schoch \\ Pedro W. Crous ${ }^{1}$ \\ Department of Plant Pathology, University of \\ Stellenbosch, P. Bag X1, Matipland 7602, South \\ Africa \\ Brenda D. Wingfield \\ Department of Genetics, University of Pretoria, Pretoriat \\ OOO2, Sonth Africa \\ Michael J. Wingfield \\ Tire Pathology Co-operative Programme, Fonestry and \\ Agricultural Biolechnology Instimule (FABI), University \\ of Preloria, Pretoria OOO2, Somblh Africa
}

\begin{abstract}
Cylindrocladium candelatmom-like isolates were collected from a wide variety of geographic locations and compared based on their morphology, sexual compatibility and the nucleotide sequences of their rDNA ITS regions. All isolates included in this study mated to produce Calonectria teleomorphs with viable progeny. Four distinct mating populations were identified, each representing a genetically isolated, biallelic, heterothallic population. Several representative isolates of each mating population, reflecting geographic diversity, were chosen for sequence comparisons. The internal transcribed spacer (ITS) regions 1 and 2 that flank the 5.8S rDNA gene, as well as the gene itself, were sequenced and compared. All isolates representing the same group yielded similar sequences, but small, consistent differences were found between the groups. Based on these results we recognise Calonectria scoparia (anamorph Cylindrocladium candelabrum), and describe three new species, namely Calonectria pauciramosa (anamorph Cylindrocladium pauciramosum), Calonectria insularis (anamorph Cylindrocladium insularae) and Calonectria mexicana (anamorph Cylindrocladium mexicanum).
\end{abstract}

Key Words: Calonectria, ITS sequence analysis, mating studies, systematics

\section{INTRODUC.TION}

Cylindrocladium scoparium Morgan, the type species of Cylindrocladium Morgan (Cy.) (Morgan 1892), has

Accepted for publication November 9, 1998.

' Corresponding author, E-mail: pwc@maties.sun.ac.za been associated with a wide range of plant disease problems in over 30 families throughout the world (Booth and Gibson 1973, French and Menge $197^{\circ}$ Peerally 1991, Waipara et al 1996). This species is, however, the most commonly incorrectly identified taxon in the genus. After several years of extensive collection by the authors, Cy. scoparium s. s. has been confirmed from only North America, but has possibly also been introduced into Europe (Overmeyer et al 1996).

Cylindrocladium scoparium, still incorrectly treated by many researchers as synonymous with Cy. florida: um Sobers \& C. P. Seymour, has been the subject of much controversy. Victor et al (1997) used morphology, sexual compatibility, RAPD markers and $A+T$ rich total DNA polymorphisms to compare C.y. scoparium (teleomorph Cialonectria morganii Crous et al), Cy. candelabrum Viégas (teleomorph Ca. scoparia Peerally), Cy. ovaum El Gholl et al (teleomorph Ca. ovata D. Victor and Crous) and Cy. floridanum (teleomorph Ca. kyotensis Terash.). This study showed that these species represent distinct taxa. Furthermore, evidence was presented to show that more than one species possibly exists in the Cy. floridanum complex. Additionally, based on DNA fingerprinting with human minisatellite DNA as a probe, Jeng et al (1997) showed the presence of three groups of isolates in collections of Cy. floridanum from Canada and the USA.

Among the small-spored species of Cylindrocladium, Cy. scoparium has also commonly been confused with taxa such as Cy. ovatum and Cy. candelabrum. All three of the latter species are heterothallic. In a recent study Crous et al (1998) confirmed the biallelic, heterothallic nature of Cy. ovatum. In earlier studies, however, very low mating percentages were obtained for Cy. candelabrum and Cy. scoparium (Crous et al 1993a, Overmeyer et al 1996), suggesting that further research was required to elucidate their mating systems.

Cylindrocladium candelabrum, which was originally described from leaves of a Luma sp. in Brazil, was characterized by Viégas (1946) as having narrowly ellipsoidal vesicles and 1-septate conidia, 40-88 $\times 5-6$ $\mu \mathrm{m}$. Crous et al (1993a) reexamined the type specimen (LACM 440), and found it to be almost completely devoid of material, but the few conidia that 
were observed were $46-70 \times 3.5-5 \mu \mathrm{m}$, and the vesicles were ellipsoidal to narrowly obpyriform. A neotype (PREM 51045) was subsequently designated, and two isolates PPRI 4153 and 4163 identified as the two mating tester strains. The species concept of $C y$. candelabrum was complicated by Peerally (1991) who considered it synonymous with Cy. ellipticum Alfieri, Seymour \& Sobers. The latter species was later shown to be a synonym of Cy. scoparium (Crous et al 1993a). To readily distinguish these species, $C y$. scoparium was circumscribed as having ellipsoidal to pyriform vesicles (widest above the middle), while those of $C y$. candelabrum were ellipsoidal to obpyriform (widest below the middle). However, a high degree of plasticity was observed amongst Cy. candelabrum-like isolates. This was particularly true in their vesicle shape, conidiophore branching pattern and conidial dimensions. Due to the low mating type frequency of isolates in previous studies, no clear indication was obtained on the nature and relevance of this variation amongst Cy. candelabrum isolates, and the species was accepted as being highly variable.

Molecular tools have become increasingly useful in providing additional evidence that has supported the interpretation of morphological variation. Several techniques including protein profiles (Crous et al 1993a), RAPD (Victor et al 1997) and RFLP (Crous et al 1997b), have been applied to the taxonomy of Cylindrocludium spp. The nucleotide sequences of the ribosomal DNA (rDNA) region contain intermittent functional and nonfunctional regions (Furlong et al 1983). The more conserved rDNA genes allow for comparisons between higher taxa. For example, Fehner and Samucls (1995) compared the nucleotide sequences of the 285 rDNA gene from a wide range of hypocrealean taxa, including Cy. scoparium and Cy. floridanum. More variable areas are provided by intergenic regions such as the internal transcribed spacers (ITS1 and ITS2) that flank the 5.8S rDNA gene. Various researchers have used these sequences to resolve intra- and interspecies phylogenies (Nazar et al 1991, Sreenivasprasad et al 1994, Bryan et al 1005, Jeng et al 1996, Witthuhn et al 1998).

Recently Jeng et al (1997) published ITS1, ITS2 and $5.8 \mathrm{~S}$ rDNA sequences of Cy. scoparium and $C y$. floridanum. In these comparisons, one 6-bp deletion and three point mutations were found in the ITS2 region. This indicated the potential of this region to be used as a tool to differentiate between morphologically similar Cy. candelabrum-like species. Accordingly, the present study was undertaken to investigate the application of a biological species concept as well as it phylogenetic species concept to isolates provisionally accommodated in the Cy. candelabrum species complex. Using these data, it was possible to eval- uate the value of morphological characters in Cylindrocladium.

\section{MATFRIAIS ANI METHODS}

Isolates.Cylindrocladium candelabrum isolates were either obtained from symptomatic material or they were baited from soil samples. Soil samples were collected and treated as explained in Crous et al (1997a). Type specimens were lodged at the National Collection of Fungi in Pretoria (PREM), and ex-type cultures maintained in the culture collection of the Department of Plant Pathology, University of Stellenbosch, South Africa (STE-U).

Sexual compatibility.-One hundred single conidial Cy. candelabrum-like isolates (listed under the results), originating from various geographic locations were mated in all possible combinations. This was achieved by removing $3 \mathrm{~mm}$ diam agar plugs from the periphery of actively growing cultures and placing them on CIA plates as described by Crous et al (1993a). Two different isolates were placed in a Petri clish with carnation leaves between them. Following this, plates were packed in stacks of 10 , sealed in plastic bags and incubated on the laboratory bench at 22 C. Protoperithecia appeared after 2 wk and successful matings were determined after 2 mo of incubation. Successful matings were regarded as those isolate combinations that produced peritheciat with fertile, extruding ascospores. Mating groups were subsequently distinguished and strains that resulted in prolific matings were selected from each group. For each mating group identified, ascospores were obtained from two matings, involving fou separate isolates. Seven single ascospores were sub-cultured for each mating group, and these were crossed in all possible combinations in order to reconfirm the biallelic. heterothallic nature of each mating population. Two isolates of opposing mating type were selected as tester strains from these isolates, and these were subsequently mated with the tester strains of the other groups to reconfirm that no mating was occurring between groups.

Sequence comparisons.-Four isolates, two isolates per mating type, of each mating group (species), representing a wide geographic distribution (TAB1.1. I), were selected for sequencing. Single conidial isolates were grown on MEA plates and plugs were transferred into $500 \mathrm{~mL}$. Erlenmeyer flasks containing $100 \mathrm{~mL}$. liquid MEA broth. Flasks were shaken at $25 \mathrm{C}$ and $125 \mathrm{rpm}$ for approximately $7 \mathrm{~d}$. Mycelium was collected by filtration (Whatman no. 1 filter paper) and DNA was extracted as described by Crous et al (1993b). Both strands of the ITS1 and ITS2 intergenic spacers as well as the $5.8 \mathrm{~S}$ ribosomal gene were sequenced and compared. Sequences were deposited at GenBank (AF059280-AF059283). DNA was amplified using the primers ITS1 (5'-dTCCGTAGGTGAACCTGCGG) and ITS4 (5'-dTCCTCCGCTTATTGATATGC) (White et al 1990). The region amplified was the $5.8 \mathrm{~S}$ ribosomal gene and the two internal transcribed spacers (ITS1 and ITS2) flanking the gene. PCR amplifications were performed on a Hybaid Omnigene Temperature Cycler (Hybaid, Middlesex, UK). Reactions comprised of $1 \mu \mathrm{L}$. Expand High Fidelity DNA polymer- 
T.ві.F. I. Isolates selected for sequencing

\begin{tabular}{ccl}
\hline \hline & STE-U & \\
Species & No. & \multicolumn{1}{c}{ Origin } \\
\hline C. pauciramosum & 951 & Mexico \\
(Group 1) & 971 & South Africa \\
& 1160 & Colombia \\
& 1691 & Australia \\
C). candelabrum & 1674 & Brazil \\
(Group 2) & 1675 & Brazil \\
& 1676 & Brazil \\
& 1678 & Brazil \\
C). insularae & 766 & Madagascar \\
(Group 3) & 768 & Madlagascar \\
& 616 & Brazil \\
& 954 & Mexico \\
Cy. mexicanum & 927 & Mexico \\
(Group 4) & 928 & Mexico \\
& 941 & Mexico \\
& 966 & Mexico \\
\hline
\end{tabular}

ase (Boehringer Mannheim, Mannheim, (icmany) and l $\mu \mathrm{l}$. reaction buffer containing $1.5 \mathrm{mM} \mathrm{MgCl}$ (Bochringer Mannheim), with $\mathrm{MgCl}_{2}$ added to make up the final buffer concentration to $5.5 \mathrm{mM}$. Liquid paraffin oil was overlaid to prevent evaporation. Other reagents added to the final volume of 10() $\mu \mathrm{L}$ were $250 \mu \mathrm{M}$ of each NTP, $0.5 \mu \mathrm{M}$ of each primer and 25 ng DNA. PCR conditions were a denaturing step at 94 C for $1 \mathrm{~min}$ followed by 10 cycles of $56 \mathrm{C}$ for $30 \mathrm{~s}$, $72 \mathrm{C}$ for $2 \mathrm{~min}$ and $94 \mathrm{C}$ for $15 \mathrm{~s}$. This was followed by a further 20 cycles at the same settings except for a $20 \mathrm{~s}$ time increase at $72 \mathrm{C}$. PCR products were purified using Wizard PCR Preps (Promega Corporation, Madison, Wisconsin). Both strands of the PCR product were sequenced using the ABI Prism 377 DNA Sequencer (Perkin-Elmer, Norwalk, Connecticut). A Dye Terminator Cycle Sequencing Ready Reaction Kit containing AmpliTaq DNA Polymerase (Perkin-Elmer) was used for the sequencing reactions. The reactions were carried out with a concentration of 20 to $40 \mathrm{ng}$ of DNA template and $3.2 \mathrm{pmol}$ primer in a total volume of $10 \mu \mathrm{L}$. The cycle sequencing reaction was done by PCR under conditions of $96 \mathrm{C}$ for $30 \mathrm{~s}, 50$ $\mathrm{C}$ for $15 \mathrm{~s}$, and $60 \mathrm{C}$ for $4 \mathrm{~min}$. This was repeated for 25 cycles. DNA was finally purified using Centri-Sep Spin columns (Princeton Separations, Adelphia, New Jersey) and loaded onto the sequencing gel. Phylogenetic analysis of the ITS1 and ITS2 DNA sequences was performed by using the PAUP (Phylogenetic Analysis Using Parsimony) 3.1.1 program (Swofford 1993). The branch and bound algorithm, with gaps treated as a fifth character, was used. Confidence intervals were determined using a 100 bootstrap replications. All uninformative characters were ignored. Sequences of Cy. scoparium and Cy. floridanum, previously published by Jeng et al (1997), were used for comparison. In addition to this, a sequence of Fusarium subglutinans, deposited by Waalwijk et al (1996), was obtained (EMBL accession number X94167) and used as outgroup.
Morphological comparisons.-Isolates were cultured on 2 malt extract agar (MEA) (Oxoid), plated onto carnationleaf agar (CLA) (Crous et al 1992), incubated at $25 \mathrm{C}$ under near-ultraviolet light, and examined after $7 \mathrm{~d}$. Only material occurring on carnation leaves was examined. Mounts were prepared in lactophenol, examined under nomarski and phase contrast, and measurements made at $\times 1000$. Wherever possible, each measurement represents at least $30 \mathrm{ob}-$ servations, and extremes are given in parentheses. Cardinal temperature requirements for growth and cultural characteristics were determined after $6 \mathrm{~d}$ on MEA using proce dures described by Crous and Wingfield (1994), and colony colors coded according to Rayner (1970). Cultures of $C y$. candelalnum were identified using the keys of Crous and Wingfield (1994).

\section{RFSII.TS}

Sexual compatibility.-All matings between the selected isolates resulted in perithecia containing fertile ascospores, except where STE-U 216 was concerned (FIc; 1). Whether this isolate constitutes another mating population, or has lost the ability to mate, remains umresolved. Control inoculations indicated that all isolates used were self sterile. Isolates of the same mating type yielded no perithecia when mated, confirming the biallelic, heterothallic mating system commonly found in ascomycetes (Yoder et al 1986). Four distinct mating populations (Groups 1-4) were observed. No successful matings were observed between the different mating groups, and subsequent crossings between ascospore progeny of prolific mating strains confirmed the distinctiveness of the mating groups (results not shown).

Sequence analysis.-No differences were detected between isolates for their $5.8 \mathrm{~S}$ sequences. The four isolates selected per mating group (TABIE I), revealed ITS sequences that were $100 \%$ similar within each group, irrespective of geographic location. For the purpose of comparison a single sequence, representing the four isolates from one species, was subsequently used to compare isolates of the four mating populations. A number of single and double base pair substitutions and deletions were found between all the species in the ITS1 and ITS2 regions. Previous work done by Jeng et al (1997) showed one 6-bp deletion and 3 single base substitutions when the sequences of Cy. floridanum and Cy. scoparium were compared. None of the other species sequenced contained a 6-bp deletion found in the Cy. floridanum ITS2 region. Additional differences were observed in the ITS1 region of the four species in the $C y$. candelabrum complex. Single bp substitutions in the ITS2 region could distinguish Cy. floridanum from the other species' sequences, while a similar single 
A

MAT1-1

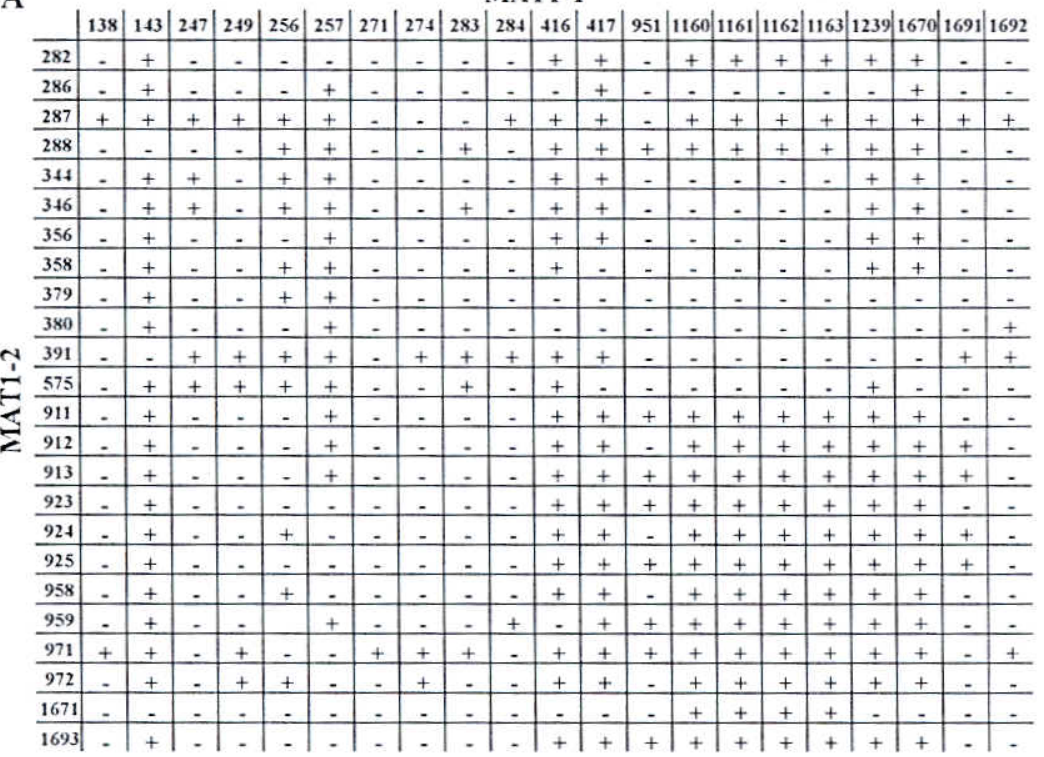

B

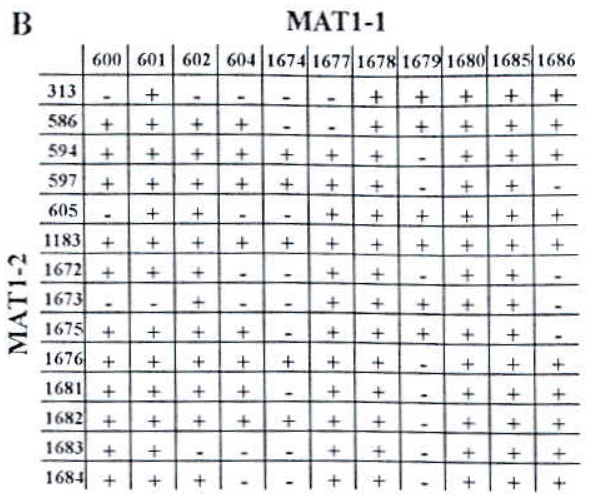

C

MAT1-1
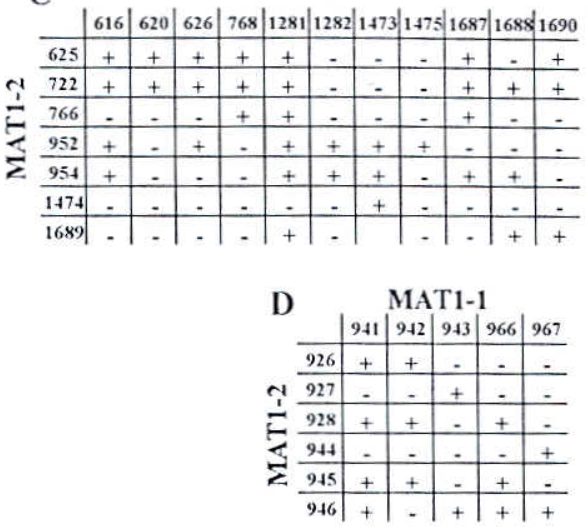

Fic. 1. Results of mating studies. Although matings were performed in all possible combinations, results are only presented between the isolates of the two different mating types (MAT1-1 and MAT1-2) in cach mating population. Horizontally numbered isslates form part of the MAT1-1 mating types and vertically mumbered isolates atre MAT1-2 mating types. When ascospores were produced the matings are inclicated as successful (+). Unsuccessful mattings are indicated with (-).

base difference could differentiate the four species in the Cy. candelabrum complex from Cy. scoparium and Cy. floridamum. Additional single base deletions and substitutions distinguished all species on the basis of sequence dissimilarity. Accordingly, a phylogenetic tree was produced using PAUP analysis (Swofford 1993). FIGURE: 2 shows one of the four most parsimonious trees obtained by branch and bound analysis of the informative sites of the ITS1, 5.8S and ITS2 DNA regions for the six species mentioned above. All f.ur most parsimonious trees indicated a closer relationship between the sequences of $C y$. insularae and those of Cy. scoparium and Cy. floridanum. The exact relationships between the other species were ambiguous.

Morphological comparisons.-Several morphological characters were studied. This included the shape and diameter of the terminal vesicles extending from the conidiophore stipes, conidial size, conidiophore braching pattern, ascospore shape, size, perithecial color, anatomy, morphology, and cultural characteristics.

The morphological similarities of the anamorph and teleomorph states corresponded well with the results obtained in the mating studies, and grouped isolates into four distinct groups. The four groups identified based on these features were further supported by their distinct DNA sequences, which led us to conclude that they represent four biological species, which are subsequently described below.

\section{Calonectria pauciramosa C. L. Schoch et Crous, sp.} nov.

FIGS. 3-10

Anamorph. Cylindrocladium pauciramosum C. L. Schoch et Crous, sp. nov.

Perithecia subglobosa ad ovoidea, 250-400 $\mu \mathrm{m}$ alta, 170 $300 \mu \mathrm{m}$ lata, crocea ad rubro-brunnea, pariete exteriore verrucosa, ostiolo papillato. Asci clavati, in stipitem longum tenuem gradatim angustatae, $70-140 \times 8-25 \mu \mathrm{m}, 8$-spori. Ascosporae hyalinae, fusiformes, 1-septatae, nihil vel leviter ad septum constrictae, $(30-) 33-38(-40) \times 6-7(-8) \mu \mathrm{m}$. Filum septatum, hyalinum (120-) $180(-230) \mu \mathrm{m}$, in vesiculam obpyriformam ad late ellipsoidam (5-)7-9(-11) $\mu \mathrm{m}$ diam terminans. Conidia cylindrica, hyalina, 1-septata, apicibus obtusis, $(30-) 45-55(-60) \times(3.5-) 4-5 \mu \mathrm{m}$. Microconidiophora ignota.

HOLOTYPES. BRAZIL $\times$ SOUTH AFRICA. BRAZIL. BA- 


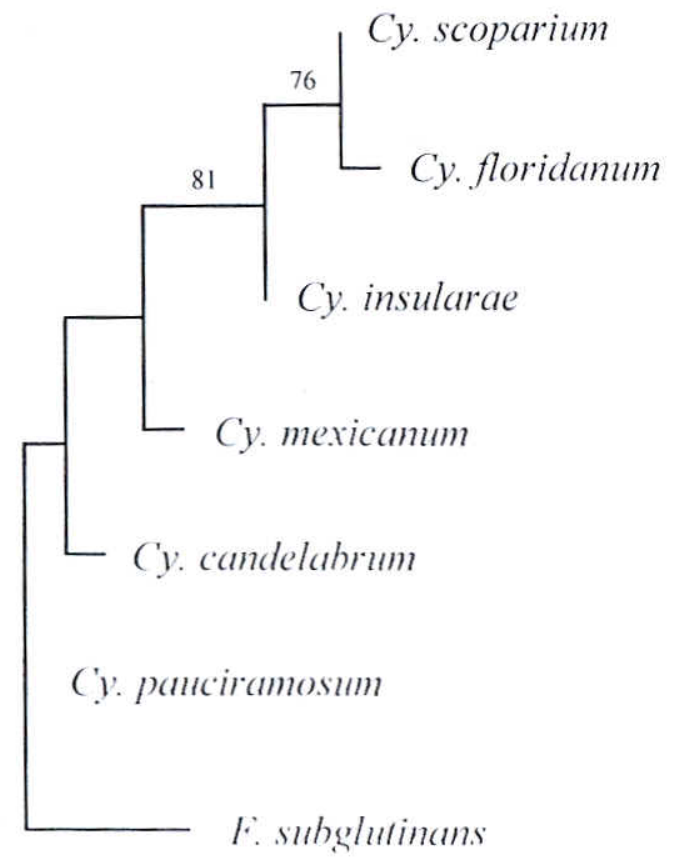

Fic. 2. () (ne of fom most parsimonions trees generated with a bauch and bound algorithm in PALP 3.1 .1 from aligned sequences of the 5.8S gene and llanking ITS1, ITS2 regioms $(15$ stcps, $(: I=0.8, \mathrm{RI}=0.786 \mathrm{i})$. Bootstrap) values alowe $50 \%$ are shown. A Fiusarimm subghlumans seguence

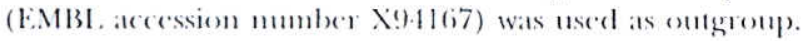

HIA: Nursery, Emalyptus sp.. Jul. I990), A. (․ Alfonas; Knysna, soil, Now. 199.1, P. IV. Coms, heterothallic mating of STEU 1670 (PREM 5575.3 anamomph) $\times$ STE-U 971 (PREM 55752 anamorph H(OLOTYPE), Арг. 1997 (. I. Sichoch (PREM 55754 teleomorph HOI.OTYPE).

Etymology. Refers to the relatively low number of conidiophore branches in the species.

Perithecia orange to red-brown, subglobose to ovoid, 250-400 $\mu \mathrm{m}$ high, 170-300 $\mu \mathrm{m}$ wide, turning dark red in 3\% KOH; ostiole papillate. Perithecia rough-walled, wall consisting of two layers: outside layer of textura globulosa, 20-50 $\mu \mathrm{m}$ wide; inner layer of textura angularis, $5-10 \mu \mathrm{m}$ wide, outer cells $40-55$ $\times 15-35 \mu \mathrm{m}$; hymenial layer of textura prismatica, hyaline, 5-10 $\mu \mathrm{m}$ wide; perithecial base up to $100 \mu \mathrm{m}$ wide, consisting of dark red, angular cells. Asci 8 spored, clavate, $70-140 \times 8-25 \mu \mathrm{m}$, tapering to a long thin stalk. Ascospores aggregated in the upper third of the ascus, hyaline, fusoid with rounded ends, straight to slightly curved, 1-septate, not or slightly constricted at the septum, (30-)33-38(-40) $\times 6-7(-$ 8) $\mu \mathrm{m}$. Macroconidiophores comprised of a stipe, a sterile elongation and a penicillate arrangement of fertile branches. Stipe septate, (120-)180(-230) $\mu \mathrm{m}$ long, terminating in an obpyriform to broadly ellipsoidal vesicle, (5-) 7-9(-11) $\mu \mathrm{m}$ diam; primary branches aseptate or 1-septate, $12-45 \times 5-6 \mu \mathrm{m}$; sec-

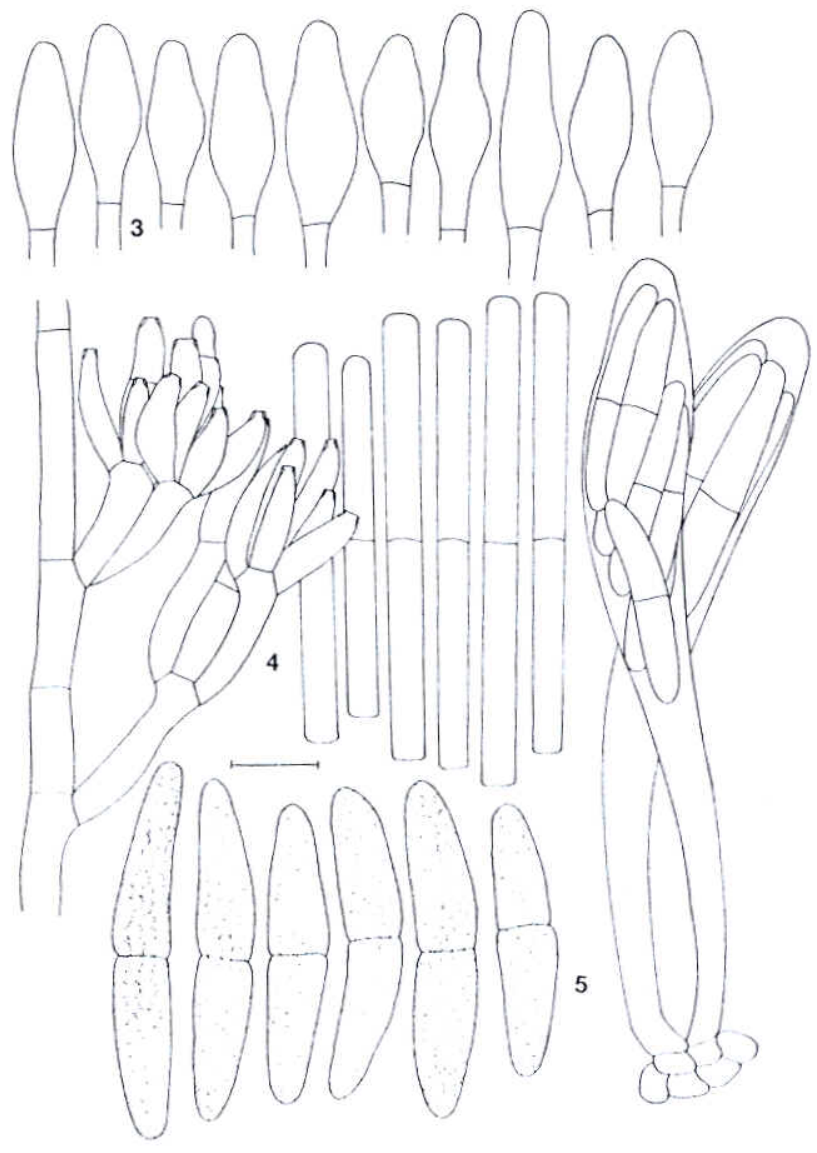

Fus. 3-5. Calomertra panciramosa and its anamorph (ylindrocladium pauriramosum. 3. Terminal vesicles on stipe extensions. 4. Conidiophore and condiat. 5. Asci and ascospores. Bar $=10 \mu \mathrm{m}$.

ondary branches aseptate, $15-20 \times 5 \mu \mathrm{m}$, and tertiary branches aseptate, $12-15 \times 5 \mu \mathrm{m}$, each terminal branch producing 2-6 phialides; phialides doliiform to reniform, hyaline, aseptate, $10-13 \times 2.5-4 \mu \mathrm{m}$, apex with minute periclinal thickening and inconspicuous collarette. Conidia cylindrical, rounded at both ends, straight, $(30-) 45-55(-60) \times(3.5-) 4-5$ $\mu \mathrm{m}$, 1-septate, lacking a visible abscission scar, held in cylindrical clusters by colorless slime. Microconidiophores not observed. Chlamydospores dark brown, thickened, formed in extensive numbers throughout the medium, and aggregated to form microsclerotia.

Cultures. Colony color (underneath) 13i fulvous, (surface) 13i sienna with abundant white aerial mycelia. Colony margin irregular, with extensive chlamydospores and sparse sporulation on aerial mycelia. Colonies obtaining a radius of $17-20 \mathrm{~mm}$ diam on MEA after $6 \mathrm{~d}$ in the dark at $25 \mathrm{C}$. Cardinal temperatures for growth were min above $5 \mathrm{C}$, max below 35 $\mathrm{C}$, opt $25 \mathrm{C}$. This is both a high and low temperature species, growing below $5 \mathrm{C}$, and above $30 \mathrm{C}$. 

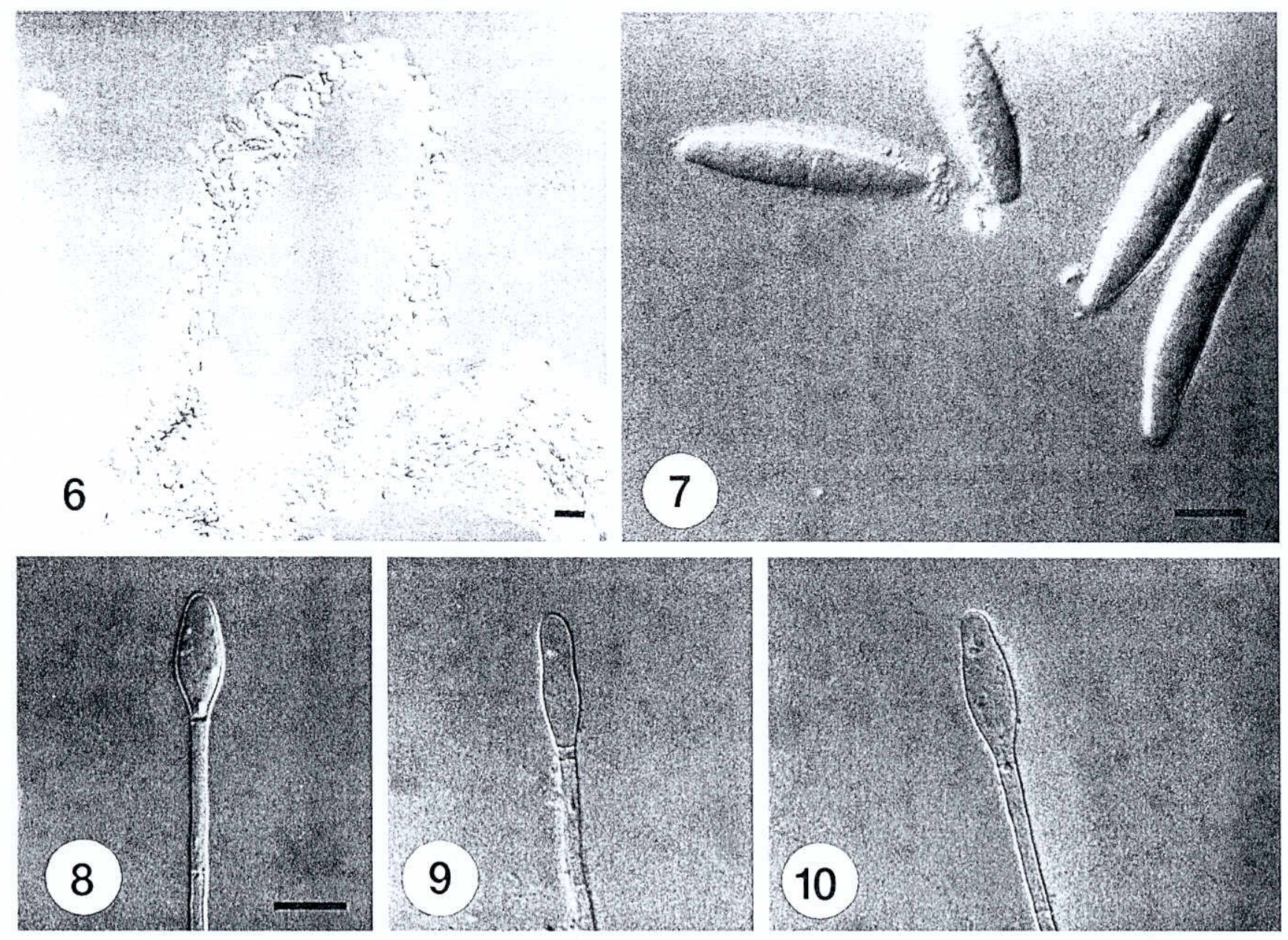

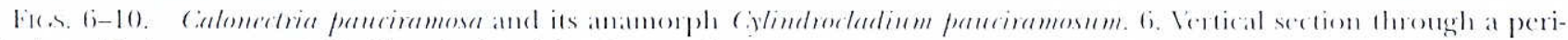
thecium. 7. Ascosperes. $8-10$. Terminal vesicles. Bans $=10 \mu m$.

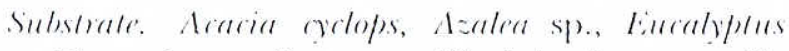

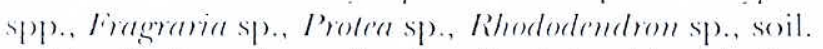

Distribution. Australia, Brazil, (colombiat, Mexicos, South Africat.

Additional cullums axamined. AUSTRALIA. (QUEENSLANI): Locality unknown, strawbers: 1991, I). Hullon $(\mathrm{N} 167 / 91=$ STE-U 1691; N335/91 = STE-U 1692). BRAZII. BAHIA: Vivicoos, Lucalyplues sp.., Jul. 1999). A. (. Alfenas (UFV 25 = STE-U 1670) UIV $27=$ STE-U 1671). SANTA

ITARINA: Florianópolis, soil, Apr. 1994, M. /. Wingfield

L-1 911-913, 923-925). COLOMBIA. CORIOB 1: La Sollat, Jun. 1995, M. /. Wing/ield (STE-U 1160)-1163). MEXICO. VERACRUZ: (atcmaco, Laguma Encantada, soil, Apr. 1994, M. /. Wingfirld (STE-U 951). SOLTH AFRICA. KWAZULU-NATAL: Kwambonambi, lincalyptus grandis seedlings, Feb. 1990, I? W. Crous (STE-U 247, 249, 256, 257, 271 , 274, 344, 346); Lucalyptus grandis, Oct. 1995, P. W. Crous (STE-U 1239); Pietermaritzburg, Eucalyptus nitens, Mar. 1990, P. W. Crous (STE-U 391); WESTERN (CAPE: Acacia

lops, Jul. 1990, M. Morris $($ CMM 953 = STE-U 1693); (. ge, Azalea bushes, Fcb. 1993, S. lamprech (STE-U 575); Knysna, soil, Nov. 1994, P. W. (Crous (STE-L 971, 972); MPLMAI.ANGA: Kruistontein, Eucralyplus grandis trunk,

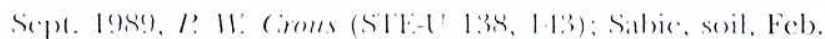

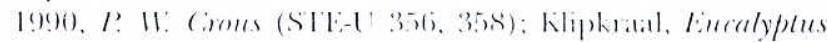

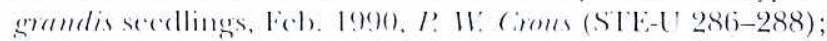

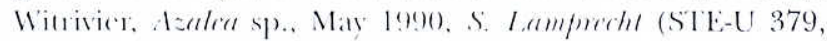
38()): N()RIIIERN PR()VIN(E: Pict Retict, pinc cuttings,

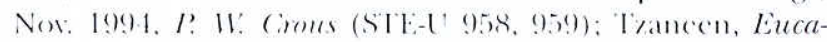
lyphus grandis scedlings, Fol). 199(). I? II: Coms (STE-U 28228-1), Eucalyptus gramdis cultings, Jun. 199(), S. de Buisson (STE-U 416, 117).

Calonectria scoparia Peerally; Mycotaxon 40: 341 (1991). Fic:s. 11-17

Anamorph. Cylindrocladium candelabrum Viégas, Bragantia 6: 370 (1946).

HOLOTYPES. BRAZIL. B.AHIA. Picadao, Conceicao de Barra, Lucalyptus grandis, Apr. 1992, A. C. Alfenas \& F. A. Ferreira (PREM 51045 NEOTYPE of teleomorph; Crous et al 1993a); Copener, Euculypus sp., A. C. Alfenas, PREM 51044 (NEOTYPE of anamorph; Crous et al 1993a), culture ex-type PPRI 4135.

Perithecia red-brown, subglobose to ovoid, 350-450 $\mu \mathrm{m}$ high, 300-350 $\mu \mathrm{m}$ wide, turning dark red in $3 \%$ 


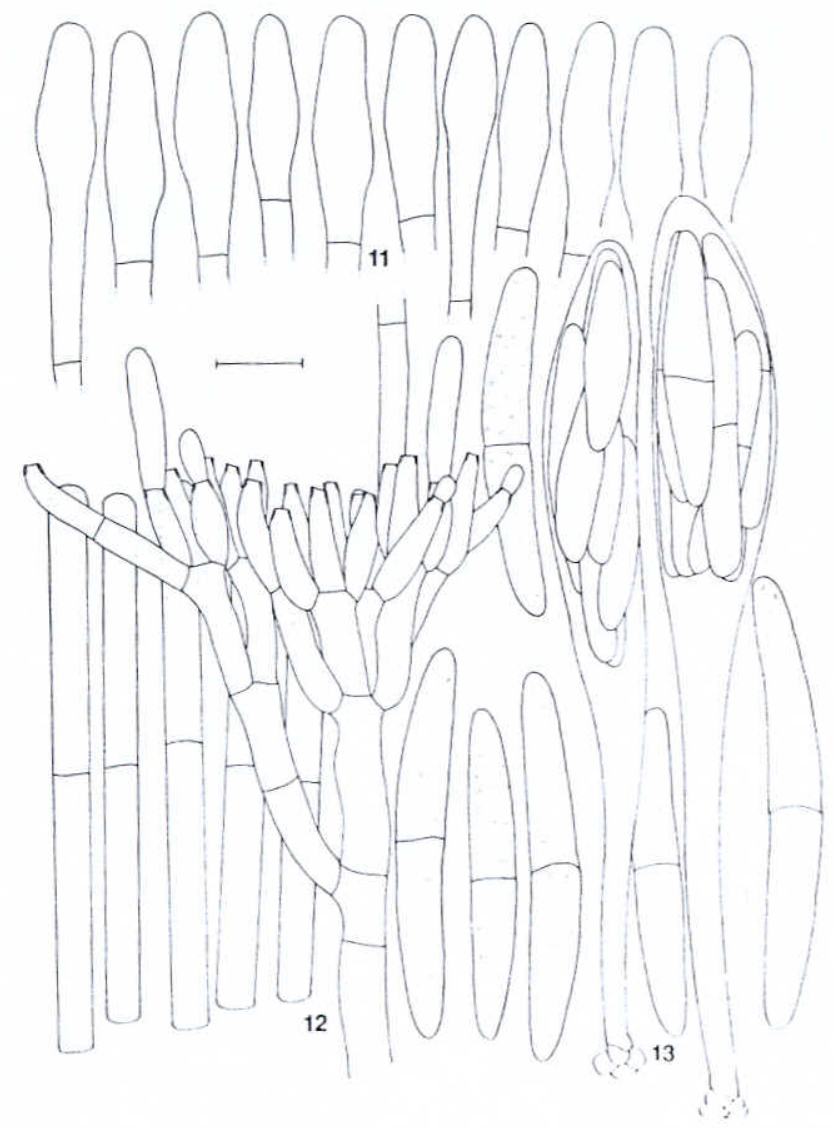

Fus. 11-13. Calometria scoparia and its anamomph ( $y$ lindrocladium candelabrum. 11. Tominal vesicles on stipe extensions. 12. Conidiophene and conicliat. 13. Asei and ascospores. Bar $=10 \mu \mathrm{m}$.
KOIl, frequently in clusters of 3-4; ostiole papillate. Perithecia rough-walled, wall consisting of two layers: outside laver of textura glolnelosa, 50-100 $\mu \mathrm{m}$ wide; inner layer of textura angularis, 5-10 $\mathrm{mm}$ wide, outer cells $35-45 \times 18-30 \mu \mathrm{m}$; hymenial layer of textura prismalica, hyaline, 5-10 $\mu \mathrm{m}$ wide; perithecial base up to $150 \mu \mathrm{m}$ wide, consisting of dark red, angular cells. Asci 8-spored, clavate, $70-130 \times 7-15 \mu \mathrm{m}$, tapering to a long thin stalk. Ascospores aggregated in the upper third of the ascus, hyaline, fusoid with rounded ends, straight to slightly curved, 1-septate, not to slightly constricted at the septum, (40-) 45$50(-60) \times 5-6 \mu m$; becoming 3 -septate once discharged. Macroconidiophores comprised of a stipe, a sterile elongation and a penicillate arrangement of fertile branches. Stipe septate, $(100-) 170(-220) \mu m$ long, terminating in an ellipsoidal to narrowly obpyriform vesicle, (5-)6-7(-8) $\mu m$ diam; primary branches aseptate or 1 -septate, $20-15 \times 4-5 \mu \mathrm{m}$; secondary branches asseptate, $15-25 \times 4-5 \mu \mathrm{m}$, tertiary branches aseptate, 15-20 $\times 4-5 \mu m$, and quaternary batuches atseptate, $10-15 \times 4-5 \mu m$, each terminal branch producing "-6 phialides; phialides doliiform (1) reniform, haline, aseptate, 10-20 $\times 3-4 \mu m$, ap $x \cdot x$ with minute periclinal thickening and inconspicuous collancelte. Comblio cylindrical, romeled at both ends, straghth, (15-)58-6is(-80) $\times 1-5(-6) \mu m, 1-s(p) t a t e$, lacking a visible abscission scar, held in cylindrical clusters by colonless slime. Microcomidiophomes non observed. (:hlamydospores dark brown, thickenced, formed in extenside mumbers thenghout the medium, and aggregated to form microselerotia.
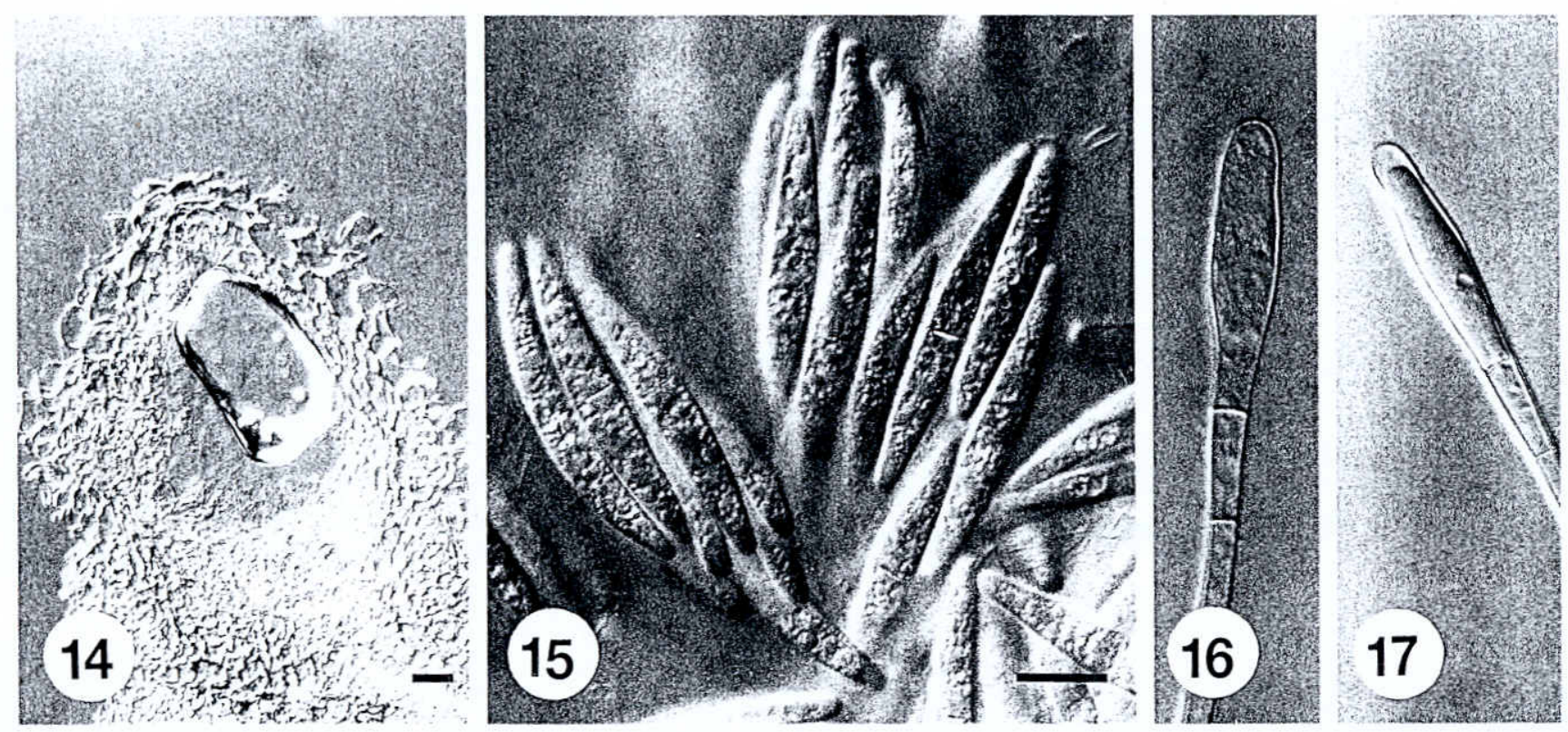

Figs. 14-17. Calonectria scoparia and its anamorph Cylindrocladium candelabrum. 14. Vertical section through a perithecium. 15. Ascospores. 16, 17. Terminal vesicles. Bars $=10 \mu \mathrm{m}$. 
Cultures. Colony color (underneath) 13i fulvous, (surface) 13i sienna. Colony margin irregular with sparse to moderate aerial mycelia, and extensive chlamydospores. Colonies obtaining a radius of 12-17 $\mathrm{mm}$ diam on MEA after $6 \mathrm{~d}$ in the dark at $25 \mathrm{C}$. Cardinal temperatures for growth were min above 5 $\mathrm{C}$, max below $35 \mathrm{C}$, opt $25 \mathrm{C}$. This is both a high and low temperature species, with medium sporulation on aerial mycelium.

Substrate. Eucalyptus spp., Luma sp., soil.

Distribution. Brazil, Venezuela.

Additional specimens deposited. BRAZIL. BAHIA: Vivieros, soil, heterotallic mating of STE-U 1675 (PREM 55755 anamorph) $\times$ STE-U 1677 (PREM 55756 anamorph), Apr. 1997, C. L. Schoch, (PREM 55757 teleomorph).

Additional cultures examined. BRAZIL. AMAZONAS: Locality unknown, Eucalyptus sp., 1991, A. C. Alfenas (UFV 117 = STE-U 1675; UFV 118 = STE-U 1676; UFV $121=$ STE-U 1677; UFV 122 = STE-U 1678; UFV 126 = STE-U 1679; UFV 128 = STE-U 1680; UFV 129 = STE-U 1681; UFV 130 = STE-U 1682; UFV 132 = STE-U 1683); Eucalyptus sp., 1991, J. C. I Dianese (D) 1038 = STE-U 1684); Belém, Lucalyphus sp., F(b. 1990, M. J. Wing/ield (STE-U 313); BAHIA: Copener, lincalyphus sp.. Jul. 1990, A. C: Alfonas (UFV 6.3 $=$ STE-U 1674); Vivicros, lucralyphus sp., Jul. 1999), A (AA: (UIV $29=$ STL-U 1672); MINAS (GERAIS: Ipatinga, Luralyphus sp., Ju1. 1999), A. (: Alfornas (UFV 45 = STE-U 167.3); Becainial, luculyptus sp., Jul. 1990, A. (: Alfornas (UFV 170)

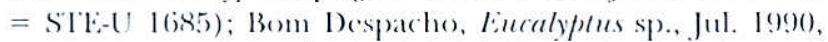

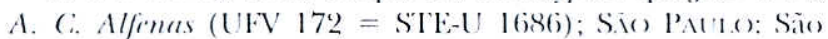

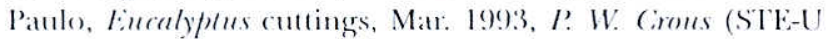

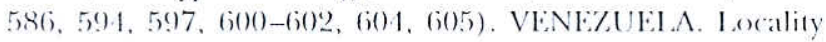
monown, soil, Jun. 1995, M. J. Wing/inld, (STE-U 11833 ).

Calonectria insularis C. L. Schoch et Crous, sp. nov.

FIc:s. 18-24

Anamorph. Cylindrocladium insularae C. L.

Schoch et Crous, sp. nov.

Perithecia subglobosa ad ovoidea, 350-450 $\mu \mathrm{m}$ alta, 300$350 \mu \mathrm{m}$ lata, crocea ad rubra, pariete exteriore verrucosat, ostiolo papillato. Asci clavati, in stipitem longum tenuem Bratlatim angustatae, 7()$-120 \times 7-18 \mu \mathrm{m}, 8$-spori. Ascosporae hyalinae, fusiformes, 1 -septatae, ad septum nihil constrictae, (27-) 30-36(-42) $\times 5-6(-7) \mu \mathrm{m}$. Ascosporae evolentes usque ad constrictae dismissae ab asco. Filum septatum, hyalinum (110-) $160(-250) \mu \mathrm{m}$, in vesiculam obpyriformam ad late ellipsoidam (4-)7-10(-13) $\mu \mathrm{m}$ diam terminans. Conidia cylindrica, hyalina, 1-septata, apicibus obtusis, (33-) 40-50(-60) $\times 3.5-4 \mu \mathrm{m}$. Microconidiophora ignota.

HOLOTYPES. MADAGASCAR: Tamatave, soil, Apr. 1997, 1. IV. Crous, heterothallic mating of STE-U 766 (PREM 55758 anamorph HOLOTYPE) $\times$ STE-U 768 (PREM 55759 anamorph), Apr. 1997, C. L. Schoch, (PREM 55760 teleomorph HOLOTYPE).

Etymology. In reference to its geographic distribution.

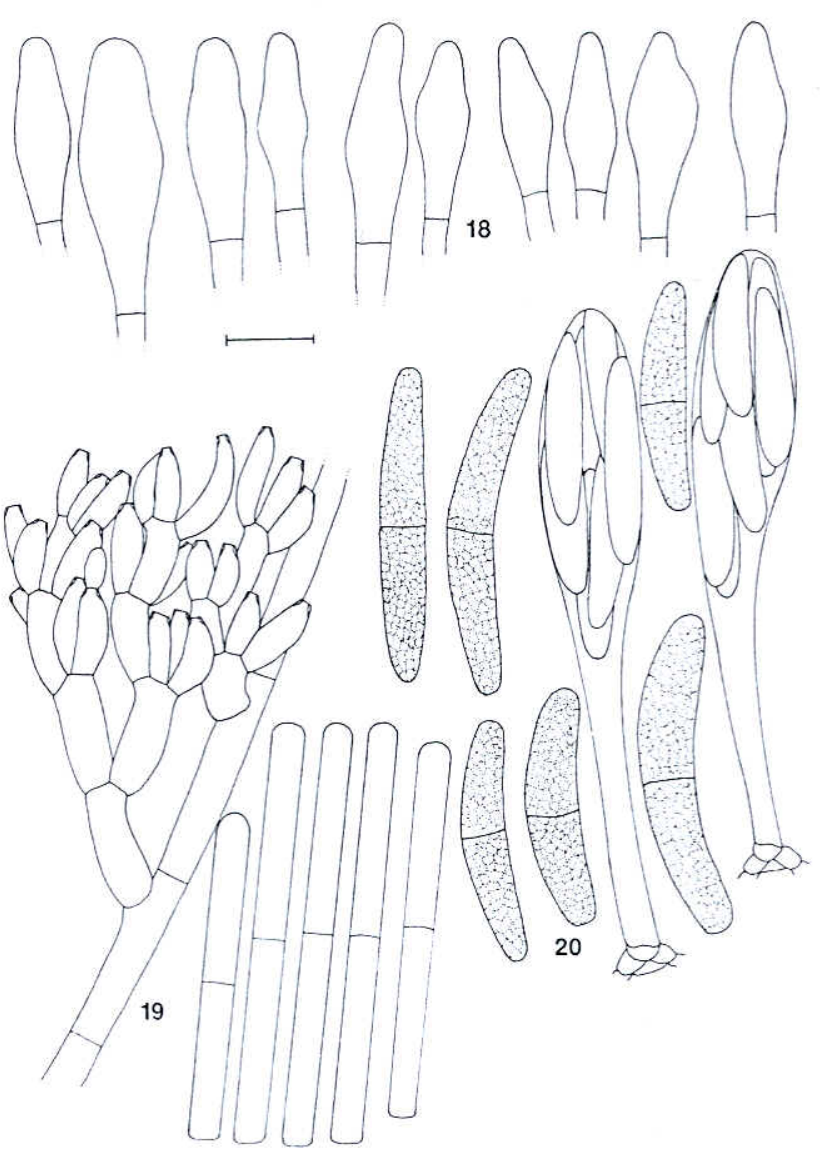

Fus. 18-20. Calonectria insularis and its anamorph Cylindrocladium insularae. 18. Terminal vesicles on stipe ex(ensions. 19. (onicliophore and conidia. 20. Asci and ascospores. Bar $=10 \mu \mathrm{m}$.

Perithecia orange to red, subglobose to ovoid, $350-$ $450 \mu \mathrm{m}$ high, 300-350 $\mu \mathrm{m}$ wide, turning dark red in $3 \% \mathrm{KOH}$; ostiole papillate. Perithecia rough-walled, wall consisting of two layers: outside layer of textura globulosa, 40-80 $\mu \mathrm{m}$ wide; inner layer of textura angularis, 5-10 $\mu \mathrm{m}$ wide, outer cells $25-45 \times 20-35$ $\mu \mathrm{m}$; hymenial layer of textura prismatica, hyaline, 5$10 \mu \mathrm{m}$ wide; perithecial base up to $100 \mu \mathrm{m}$ wide, consisting of dark red, angular cells. Asci 8-spored, clavate, $70-120 \times 7-18 \mu \mathrm{m}$, tapering to a long thin stalk. Ascospores aggregated in the upper third of the ascus, hyaline, fusoid with rounded ends, straight to slightly curved, 1-septate, not constricted at the septum, becoming constricted once discharged, (27-) $30-$ $36(-42) \times 5-6(-7) \mu \mathrm{m}$. Macroconidiophores comprised of a stipe, a sterile elongation and a penicillate arrangement of fertile branches. Stipe septate, (110-) 160 $(-250) \mu \mathrm{m}$ long, terminating in an obpyriform to broadly ellipsoidal vesicle, (4-)7-10(-13) $\mu \mathrm{m}$ diam; primary branches aseptate or 1-septate, $10-45 \times 4$ $5 \mu \mathrm{m}$; secondary branches aseptate, $10-25 \times 4-5$ $\mu \mathrm{m}$, tertiary branches aseptate, $10-17 \times 4-5 \mu \mathrm{m}$, and 

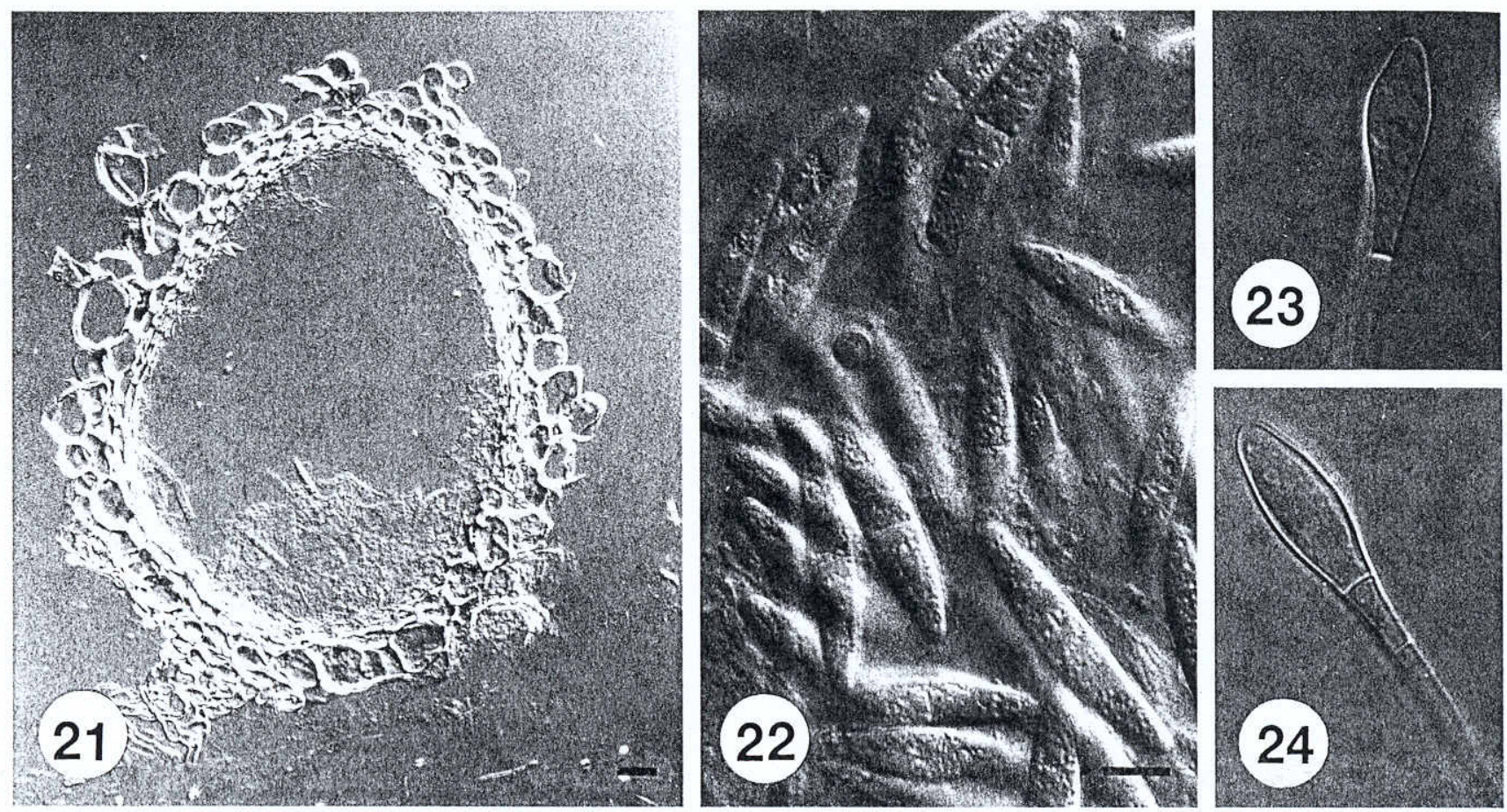

Fis:s. 21-24. Calonetria insularis and its anamoph (y)lindrocladium insularae. 21. Vertical section through at perithecium. 22. Ascosperes. 23, 24. Terminal vesicles. Bars $=10 \mu \mathrm{m}$.

quaternary branches aseptate, $10-12 \times 4-5 \mu \mathrm{m}$, each terminal branch producing $2-6$ phialides; phialides doliiform to reniform, hyaline, aseptate, 9-14 $\times 3-5$ $\mu m$, apex with minute periclinal thickening and inconspicuous collarette. Comidia cylindrical, rounded at both ends, straight, $(33-) 40-50(-60) \times 3.5-4 \mu \mathrm{m}$, 1-septate, lacking a visible abscission scar, held in cylindrical clusters by colorless slime. Microconidiophores not observed. Dark brown, thickened chlamydospores formed in extensive numbers throughout the medium, and aggregated to form microsclerotia.

Cultures. Same characteristics as Cy. pauciramosum with colonies obtaining a radius of $18-23 \mathrm{~mm}$ diam on MEA after $6 \mathrm{~d}$ in the dark at $25 \mathrm{C}$. Cardinal temperatures for growth were $\min$ above $15 \mathrm{C}$, max above $35 \mathrm{C}$, opt $25-30 \mathrm{C}$. This is a high temperature species.

Substrate. Acacia sp., Auracaria heterophylla, Medicago sativa, Persea americana, Pisum sativum, Eucalyptus sp., soil.

Distribution. Brazil, Hawaii, Indonesia, Madagascar, Malaysia, Mauritius, Mexico.

Additional cultures examined. BRAZIL. AMAZONAS: Belém, soil, Apr. 1993, M. J. Wingfield (STE-U 616, 620, 625, 626). INDONESIA. SUMATRA: Sei Kobaro, Acacia mangium rhizosphere, Jan. 1994, A. C. Alfenas (STE-U 722). MADAGASCAR. Tamatave, soil, Apr. 1994, P. W. Crous (STE-U 766, 768). MALAYSIA. MALAY PENINSULA: Kemasik, Acacia sp., Dec. 1995, M. J. Wingfield (STE-U 1281, 1282). MAURITIUS. Rivière Noire, soil, Apr. 1996, H. Smith
(STE-U 1473, 1474). P'ampalmousses, soil, Apr. 1996, 11. Smith (STE-U 1475). MEXIC(O). VERACRUZ: Concjos, Pu("nte Nacional, soil, $\Lambda$ pr. 1994, M. J. Wing/ield (STE-U 952, 954). USA. HAWAII: Locality unknown, Medicago satiza, 1981, M. Aragaki (A 890) = STE-U 1687); Auracaria helerophylla, 1987, M. Aragaki (A 1570) = STE-U 1688); Pisum satizum, 1988, M. Aragaki (A 1823 = STE-U 1689); Persea americana, 1988, M. Aragaki (A 1853) = STE-U 1690).

Calonectria mexicana C. L. Schoch et Crous, sp. nov. FI(;S. 25-34

Anamorph. Cylindrocladium mexicanum C. L. Schoch et Crous, sp. nov.

Perithecia subglobosa ad ovoidea, 400-450 $\mu \mathrm{m}$ alta, 350$450 \mu \mathrm{m}$ lata, crocea ad rubra, pariete exteriore verrucosa, ostiolo papillato. Asci clavati, in stipitem longum tenuem gradatim angustatae, $70-120 \times 10-20 \mu \mathrm{m}, 8$-spori. Ascosporae hyalinae, fusiformes, 1-septatae, nihil vel leviter constrictae ad septum, (35-)40-55(-65) × 5-6(-7) $\mu \mathrm{m}$. Ascoporae evolentes usque ad tres septa dismissae ab asco. Filum septatum, hyalinum (160-) $180(-250) \mu \mathrm{m}$, in vesiculam late ellipsoidam apicibus papillatis (7-) $8-10(-12) \mu \mathrm{m}$ diam terminans. Conidia cylindrica, hyalina, 1-septata, apicibus obtusis, (35-)40-48(-52) × 3-4(-4.5) $\mathrm{mm}$. Microconidiophora ignota.

HOLOTYPES. MEXICO. YUCATAN: Uxmal, soil., Apr. 1994, M. J. Wingfield; HOLPECHÉN: Campeche, soil., Apr. 1994, M. J. Wingfield, heterothallic mating of STE-U 927 (PREM 55761 anamorph HOLOTYPE) $\times$ STE-U 941 (PREM 55762 anamorph), Apr. 1997, C. L. Schoch (PREM 55763 teleomorph HOLOTYPE). 


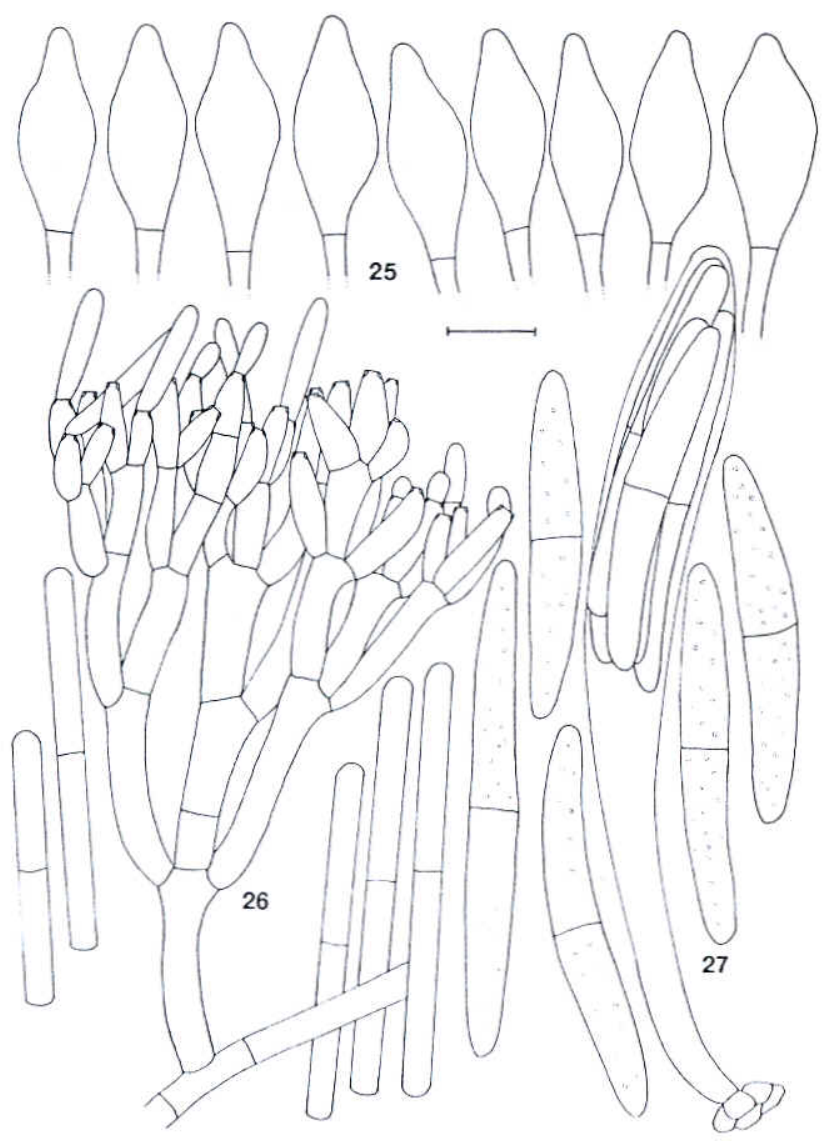

Fle:s. 25-27. Calonertrin mexiranat and its anamorph (ylindrocladium mexiranum. 25. Terminal vesicles on stipe extensions. 26. Conicliophore and coniclia. 27. Asci and aseofores. Bar $=10 \mu \mathrm{m}$.

Etymology. In reference to its country of origin.

Perithecia orange to red, subglobose to ovoid, 400$450 \mu \mathrm{m}$ high, 350-450 $\mu \mathrm{m}$ wide, turning dark red in $3 \% \mathrm{KOH}$; ostiole papillate. Perithecia rough-walled, wall consisting of two layers: outside layer of textura globulosa, 35-90 $\mu \mathrm{m}$ wide; inner layer of textura an8.thris, 5-15 $\mu \mathrm{m}$ wide, outer cells 20-35 $\times 20-30$ $\mu \mathrm{m}$; hymenial layer of textura prismatica, hyaline, 5$10 \mu \mathrm{m}$ wide; perithecial base up to $100 \mu \mathrm{m}$ wide, consisting of dark red, angular cells. Asci 8-spored, clavate, $70-120 \times 10-20 \mu \mathrm{m}$, tapering to a long thin stalk. Ascospores aggregated in the upper third of the ascus, hyaline, fusoid with rounded ends, straight to slightly curved, 1-septate, not or slightly constricted at the septum, (35-)40-55(-65) × 5-6(-7) $\mu \mathrm{m}$; becoming 3-septate once discharged. Macroconidiophores comprised of a stipe, a sterile elongation and a penicillate arrangement of fertile branches. Stipe septate, (160-) $180(-250) \mu m$ long, terminating in a broadly ellipsoidal vesicle with a papillate apex, (7) $8-10(-12) \mu \mathrm{m}$ diam; primary branches aseptate or l-septate, 17-45 × 4-6 $\mu \mathrm{m}$; secondary branches asep- tate, 15-25 $\times 4-5 \mu \mathrm{m}$, tertiary branches aseptate, $11-$ $17 \times 3-5 \mu \mathrm{m}$, and quaternary branches aseptate, 10 $15 \times 2.5-4 \mu \mathrm{m}$, each terminal branch producing $2-$ 6 phialides; phialides doliiform to reniform, hyaline, aseptate, $7-16 \times 3-4 \mu \mathrm{m}$, apex with minute periclinal thickening and inconspicuous collarette. Conidia cylindrical, rounded at both ends, straight, (35-)40$48(-52) \times 3-4(-4.5) \mu \mathrm{m}, 1$-septate, lacking a visible abscission scar, held in cylindrical clusters by colorless slime. Microconidiophores not observed. Chlamydospores dark brown, thickened, formed in extensive numbers throughout the medium, and aggregated to form microsclerotia.

Cultures. Colony color (underneath) 13b-13i (orange to sienna), (surface) similar as underneath with moderate white aerial mycelia. Colony margin irregular with extensive chlamydospores and sparse sporulation on aerial mycelium. Colonies obtaining a radius of $17-20 \mathrm{~mm}$ diam on MEA after $6 \mathrm{~d}$ in the dark at $25 \mathrm{C}$. Cardinal temperatures for growth were $\mathrm{min}$ above $10 \mathrm{C}$, $\max$ above $35 \mathrm{C}$, opt $25-30 \mathrm{C}$. This is both a high and low temperature species.

Substrate. Soil.

Distribution. Mexico.

Additional cullures examined. MEXICO. CAMPECHE: Ilolpechén, soil, Apr: 1994, M. J. Wingfield (STE-U 941-943, 966, 967); YUC:ATAN: Uxmal, soil, Apr. 1994, M. J. Wingfirld (STE-U 926-928, 944-946).

\section{1)IS(:TSSION}

This study was initiated in order to investigate the morphological variability observed within the Cy. candelabrum species complex. Mating studies revealed the existence of four distinct mating populations in this complex. These findings were further supported by differences in morphology, and sequence data. In accordance with the biological species concept, different species were therefore proposed for each mating population.

Previous mating studies between isolates of Cy. scoparium and Cy. candelabrum showed these species to be genetically isolated (Crous et al 1993a). Within the Cy. candelabrum-complex, however, prominent differences were observed when perithecia of South African $\times$ South African, or South African $\times$ Brazilian matings were compared with some Brazilian $\times$ Brazilian matings. In light of the distribution data of some of these species (Cy. pauciramosum and Cy. candelabrum) as circumscribed in the present study, it is obvious that the variation observed by Crous et al (1993a) can now be ascribed to different biological species. In light of the results presented here, previous mating groups observed in Cy. candelabrum (as Cy. scoparium; Ribeiro 1978), suggest that yet other, 

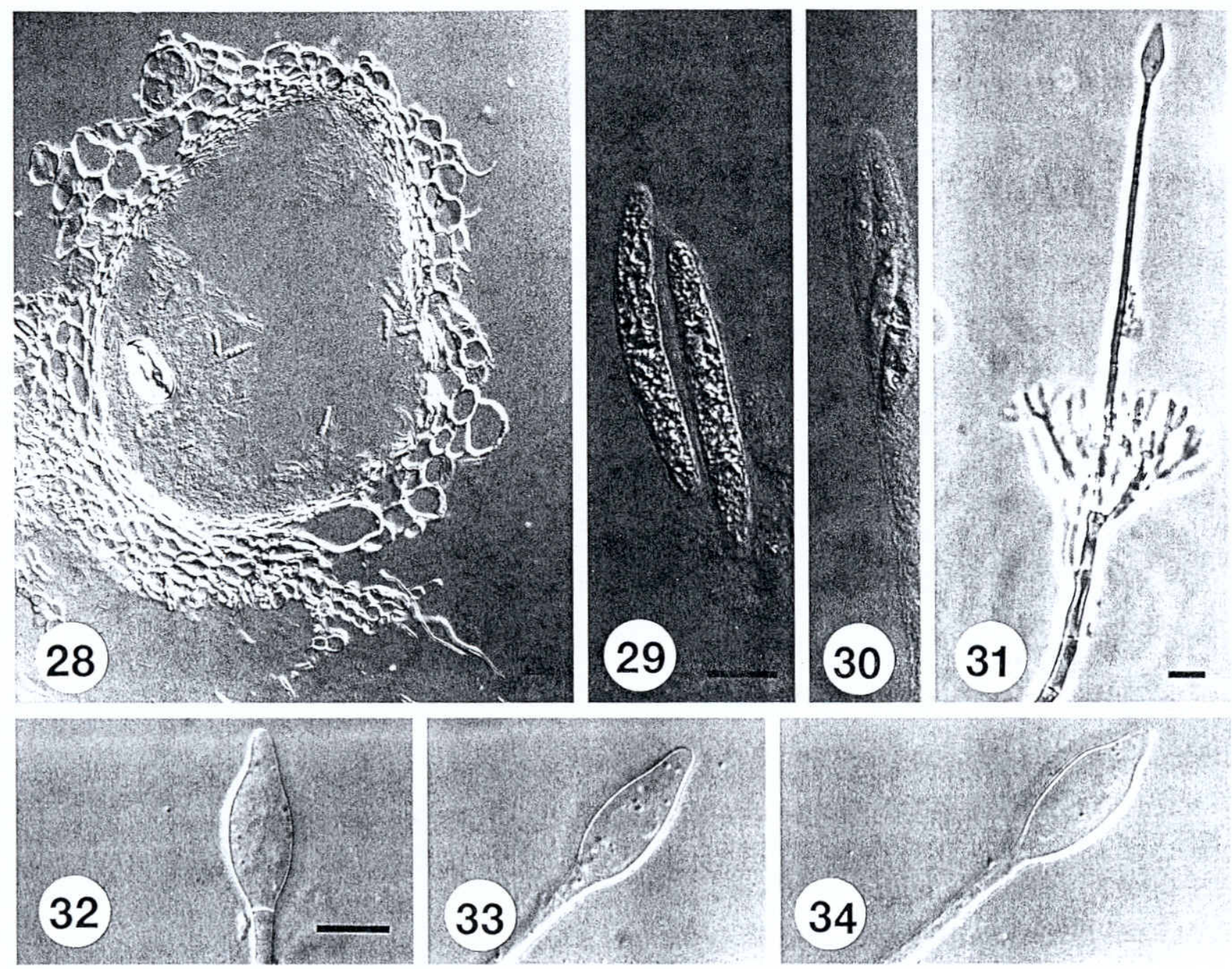

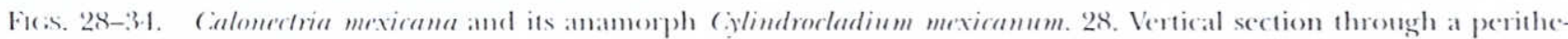
cium. 29. Ascospores. 30. Asci. 31. Conicliophore with extending stipe and terminal vesicle. 32-34. Terminal vesicles. Bars = 10 $\mu \mathrm{m}$.

undescribed biological species could exist in this complex. Recent molecular work done in another homothallic species complex, Cy. floridamum (Victor et al 1997), suggests that this aggregation of distinct biological taxa in species complexes is much more common in Cylindrocladium than expected earlier.

The high proportion of successful matings obtained in the present study, and recently by Crous et al (1998) in Cy. ovatum, can possibly be ascribed to the fact that these matings were conducted at $22 \mathrm{C}$, compared to previous studies that used 15 and $25 \mathrm{C}$ as optimum temperature. Within each species, however, isolates showed varying degrees of success in mating with opposing mating types. For example, in Cy. pauciramosum STE-U 138 mated only with two other opposing mating type strains, while in Cy. candelabrum STE-U 1678 mated successfully in all instances. Age of isolates as well as differences in their female fertility could account for this variation. It appears that Cy. pauciramosum and Cy. insularae are largely allopatric in character, with isolates available from various localities.

Sequence data can quantify relatedness among taxa, and is commonly used to clarify different taxonomic questions (Viljoen et al 1993, Rehner and Samuels 1995). The sequences of the ITS1 and 2 flanking regions of the $5.8 \mathrm{~S}$ ribosomal gene indicated small, but consistent differences between the species proposed in this study. Although a high degree of sequence variation in this region has been reported before (Chambers et al 1986), a low amount of variation was observed between the Cylindrocladium species examined in the present study. Within a biological species no variation could be observed at all. Even in the case of Cy. insularae, identical sequences were observed for isolates from disparate geographic 
areas like Madagascar, Mexico and Brazil. When compared to a similar situation in Gibberella fujikuroi, where several mating populations exist between isolates with similar morphological features (Leslie 1995), the high relatedness in the Cy. candelabrum complex becomes more evident. However sequences of the 5.8S gene and ITS1 and 2 flanking regions proved problematic in differentiating the different mating populations in the Gibberella fujikuroi complex (Waalwijk et al 1996). Although the species in this study could be differentiated using sequence results, further consideration will have to be given to other, more variable DNA regions. Studies conducted in the hypocrealean genus Fusarium (O'Donnell 1996), could prove useful in this regard.

Crous et al (1997a) recently provided a key to $\mathrm{Ca}$ lonectria spp. with Cy. candelabrum-like anamorphs that have 1-septate conidia. The following key can therefore be used in conjunction to identify the species occurring in the Cy. candelabrum complex.

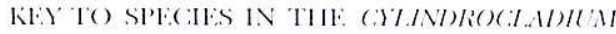 (ANDHIABRLM COMPILX}

1. Vesickes boroally ellipsoidlal with at papillate at)ex, (7-) $8-10(-12) \mu m$... (.y. mexicamum (teleo. Cia. mexicana)

1. Vesicles not as above ................ 2

2. Vesicles ellipsosidal to narrowly obpyriform, (5-)6$7(-8) \mu m$, perithecia, red-borown, ascospores (40-) $45-50(-60) \times 5-6$ Hm, coniclia $(45-) 58-68(-80)$ $\times 4-5(-6) \mu \mathrm{m} \ldots \ldots \ldots \ldots \ldots \ldots \ldots \ldots$

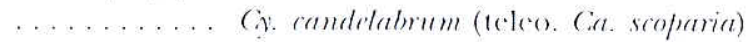

2. Vesicles obpyriform to ellipsoidal (4-) 7-10(-13), perithecia orange to red or orange to red-bown, ascospores shorter than $42 \mu \mathrm{m}$, conicliat shorter

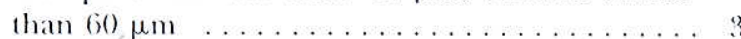

3. Conicliophores lacking quaternary branches, perithecia orange to red-brown, ascospores $6-7(-8) \mu m$ wicle ........ Cy. pauciramosum (teleo. Ca. pauciramosa)

3. Conidiophores commonly with quaternary branches, perithecia orange to red, ascospores 5-6(-7) $\mu \mathrm{m}$ wide ......... Cy. insularae (teleo. Ca. insularis)

\section{ACKNOWLEDGMENTS}

The authors wish to thank Prof. A. C. Alfenas and other collectors for providing isolates examined in this study, and Dr. J. E. Taylor for providing microtome sections of the perithecia. This research was supported by the Foundation for Research Development (FRD), South Africa.

\section{I.ITERATURE: (ITTED)}

Booth C, Gibson IAS. 1973. Cylindrocladium scoparium. CMI Descr Pathog Fungi Bact Nr 362.

Bryan GT, Daniels MJ, Osbourn AE. 1995. Comparison of fungi within the Garumannomyces-Phialophora complex by analysis of ribosomal DNA sequences. Appl Environ Microbiol 61:681-689.

Chambers C, Dutta SK, Crouch RJ. 1986. Neurospora crassa ribosomal DNA: sequence comparison with $N$. intermedia and $N$. sitophila. Gene 44:159-164.

Crous PW, Alfenas AC, Junghans TG. 1998. Variability within Calonectria ovata and its anamorph Cylindrocladium ovatum from Brazil. Sydowia 50:1-13.

$\longrightarrow$ - - Wingfield MJ. 1993a. Calonectria scoparia and Calonectria morganii sp. nov. and variation among isolates of their Cylindrocladium anamorphs. Mycol Res 97:701-708.

_- Janse BJH, Victor D, Marais GF, Alfenas AC. 1993b. Characterization of some Cylindrocladium species with three septate coniclia using morphology, isozyme, banding patterns and DNA polymorphisms. Syst Appl Microbiol 16:266-273.

_- Mchau GRA, Van Zyl WH, Wingfield MJ. 1997a. New species of Calonectria and Cylindrocladium isolated from soil in the tropics. Mycologia 89:653-660.

_- Phillips AJL, Wingfield MJ. 1992. Effects of cultural conditions on vesicle and conidlum morphology in species of Cylindrocladium and Cylindrocladiella. Mycologia 84:497-504.

- Theron L, Van Zyl WH. 1997b. Delineating C. candelatrum spp. with 1-3-septate conidia and clavate vesicles based on morphology and rDNA RFLPs. Mycol Res 101:210-214.

—, Wingficld MJ. 1994. A monograph of Cylindrocledium, including anamorphss of Calomertria. Mycotaxon $51: 341-345$.

French DW, Menge JA. 1978. Survival of Cylindrocladium floridanum in naturally and antificially infested soil forest tree nurseries. Pl Dis Rep (62:806-810.

Furlong JC, Forbes J, Robertson M, Maden BEH. 1983. The external transcribed spacer and preceding region of Xenopus borealis rDNA: comparison with the corresponding region of Xenopus larvis rDNA. Nucl Acids Res 11:8183-8196.

Jeng R, Hintz WE, Bowden CG, Horgen PA, Hubbes M. 1996. A comparison of the nucleotide sequence of the cerato-ulmin gene and the rDNA ITS between aggressive and non-aggressive isolates of Ophiostoma ulmi sensu lato, the causal agent of Dutch elm disease. Curr Genet 29:168-173.

—_, Dumas M, Liu FH, Wang CL, Hubbes M. 1997. DNA analysis of Cylindrocladium floridanum isolates from selected forest nurseries. Mycol Res 101:285-291.

Leslie JF. 1995. Gibberella fujikuroi: available populations and variable traits. Can J Bot 73:S282-S291.

Morgan AP. 1892. Two new genera of hyphomycetes. Bot Gaz 17:190-192.

Nazar RN, Hu X, Schmidt J. Culham D, Robb J. 1991. Potential use of PCR-amplified ribosomal intergenic sequences in the detection and differentiation of Verticillium wilt pathogens. Physiol Mol Pl Pathol 39:1-11.

O'Donnell K. 1996. Progress towards a phylogenetic classification of Fusarium. Sydowia 48:57-70.

Overmeyer C, Lünnemann S, Von Wallbrünn C, Meinhardt F. 1996. Genetic variability among isolates and sexual 
offspring of the plant pathogenic fungus Calonectria morganii on the basis of random amplification of polymorphic DNA (RAPD) and restriction fragment length polymorphism (RFLP). Curr Microbiol 33:249-255.

Peerally A. 1991. The classification and phytopathology of Cylindrocladium species. Mycotaxon 40:323-366.

Rayner RW. 1970. A mycological colour chart. Kew, Surrey, England: CMI and British Mycological Society. 34 p 17 sheets.

Rehner SA, Samuels G. 1995. Molecular systematics of the Hypocreales: a teleomorph gene phylogeny and the status of their anamorphs. Can J Bot 73:S816-S823.

Ribeiro JO. 1978. Heterotalismo em Cylindrocladium scoparium Morgan [MSc Thesis]. Viçosa, Minas Gerais, Brazil: Universidade Federal de Viçosa. 33p.

Sreenivasprasad S, Mills PR, Brown AE. 1994. Nucleotide sequence of the rDNA spacer 1 enables identification of isolates of Colletotrichum as C. acutatum. Mycol Res 98:186-188.

Swofford DL. 1993. PAUP (phylogenetic analysis using parsimony, ver. 3.1.1.). Champaign, Illinois: Illinois Natural History Survey.

Victor D, Crous PW, Janse BJH, Wingfield MJ. 1997. Genetic variation in Cylindrocladium floridanum and other mor- phologically similar Cylindrocladium species. Syst Appl Microbiol 20:268-285.

Viégas AP. 1946. Algunos fungos do Brazil XII. Hifomicetss. Bragantia 6:353-442.

Viljoen CD, Wingfield BD, Wingfield MJ. 1993. Comparison of Seiridium isolates associated with cypress canker using sequence data. Exp Mycol 17:323-328.

Waalwijk C, De Koning JRA, Baayen RP, Gams W. 1996. Discordant groupings of Fusarium spp. from sections Elegans, Liseola and Dlaminia based on ribosomal ITS1 and ITS2 sequences. Mycol Res 88:361-368.

Waipara NW, Di Menna ME, Cole ALJ, Skip RA. 1996. Pathogenicity of Cylindrocladium scoparium to pasture clo ver and grass species. Austral Pl Pathol 25:205-211.

White TJ, Burns T, Lee S, Taylor J. 1990. Amplification and direct sequencing of fungal ribosomal genes for phylogenetics. In: Innis MA, Gelfand DH, Shinsky J, White TJ, eds. PCR protocols. A guide to methods and applications. San Diego: Academic Press. p 315-322.

Witthuhn RC, Wingfield BD, Wingfield MJ, Wolfaardt M, Harrington TC. 1998. Monophyly of the conifer species in the Ceratogystis coerulescens complex based on DNA sequence data. Mycologia 90:96-101.

Yoder OC, Valent B, Chumley F. 1986. Genetic nomenclatture and practice in plant pathogenic fungi. Phytopathology $76: 383-385$. 